\title{
MEASURING AND MAPPING CUSTOMERS' EXPECTATIONS AND PERCEPTIONS FOR AIRLINES: \\ THE SUNEXPRESS CASE WITH THE GAPS MODEL
}

\author{
Eda ATILGAN \\ Serkan AKINCI \\ Şafak AKSOY \\ Akdeniz University, Turkey
}

\begin{abstract}
Along the entire service chain in mass tourism, charter airlines play a critical role. While all the airlines in the market manifest their commitment to providing customers with a service beyond their expectations, only the firms effectively analyzing passenger expectations and their own performances can gain competitive advantage.

By focusing on the expectations and perceptions of airline passengers and visualizing them by correspondence analysis, this research makes a significant contribution to measuring and managing service dimensions in the charter airline business from the customers' viewpoint. The study concludes that identifying the service gaps and relative differences in passenger expectations and perceptions for specific service attributes guide the airline management to tailor its service offering for higher customer satisfaction.
\end{abstract}

Keywords: Expectations and perceptions, airlines, gap analysis

\section{INTRODUCTION}

There is no doubt that quality is the cornerstone of strategic management and marketing for service firms. Customer satisfaction and loyalty, as a consequence of high quality, provides long term survival and success (Robledo, 2001). In order to survive and have longterm relationships with customers, understanding them, meeting their expectations and being different from rivals are important. Hence, the concept of customer expectations and perceptions has taken considerably high attention both from researchers and practitioners. Nevertheless, the debate is still going on in different areas of service industry, especially in conceptualization and measurement of customers' viewpoint.

In services, airline industry has a considerable amount of share. It facilitates economic growth, world trade international investments and tourism. For this reason, it helps many other industries to be a part of globalization.

The profitability of airline industry is strictly parallel to the growth of economy and trade. The industry faced a crisis at the early years of 1990 s because of the stagnation in world economy and gulf war. In 1991, the number of passengers was decreased for the first time. IATA members declared approximately $\$ 20.4$ billion loss between 1990 and 1994 (De Lollis, 2002). After this experience, many airlines realize the need of a radical change for survival and continuous success. They invest heavily on service quality improvements to fill the gap between passenger needs and expectations and airline performance.

The paper begins with a description of gaps model in the literature. The relation between customer expectations and perceptions in the service context is discussed. Academic studies about airline service quality are specifically examined afterwards. The limited number of studies about service quality measurements in airline industry is the starting point of the current study. This study, therefore explores the expectations and perceptions of charter airline passengers. The gaps between expectations and perceptions of customers for different airline service 
dimensions were identified. Mapping technique was used in order to provide the service managers the advantage of ease in analysis and interpretation of customer viewpoint measurements.

\section{GAPS MODEL OF SERVICE QUALITY}

The widespread adoption of service quality concept and the close attention of the service firm managers to this concept motivate the researchers to explore more solid methods for service quality measurements and the evaluation of it (e.g. Parasuraman et al., 1988; Dabholkar et al. 1996; Brady and Cronin, 2001). For this aim, gap theory is the most accepted model in the service literature (Brown and Bond, 1995), although some criticisms about its validity is also discussed by some researchers (e.g. Teas 1993; Brown et al, 1993; Peter et al.1993).

The gaps model positions the key concepts, strategies and decisions in services marketing in a manner that begins with the customer and builds the organization's tasks around what it is needed to close the gap between customer expectations and perceptions (Zeithaml and Bitner, 2000). Not knowing what customers expect (Gap1), not selecting the right service designs and standards (Gap 2), not delivering to service standards (Gap 3), not matching performance to promises (Gap 4) are the underlying causes behind the customer gap (Gap 5). Among these five service quality gaps, customer gap is the most vital point to consider. The major aim of the gaps model is to analyze the difference between customer expectations and perceptions (see Figure 1). To increase the customer satisfaction, firms first need appropriate measurement techniques for measuring and evaluating the gap between expectations and perceptions.

For services, the assessment of quality is made during the service delivery process, which usually takes place with an encounter between a customer and a service contact person (Fitzsimmons and Fitzsimmons, 1994). Customer satisfaction with service quality can be defined by comparing perceptions of services with expectations of service desired (See Figure 2). After receiving the service, customers compare the performance of the service provider with their expectations which are mainly influenced by word of mouth communication, personal needs and past experience.

In most of the service settings, however, customers may not get the service level they expected before the

\section{Figure 1. Gaps Model of Service Quality}

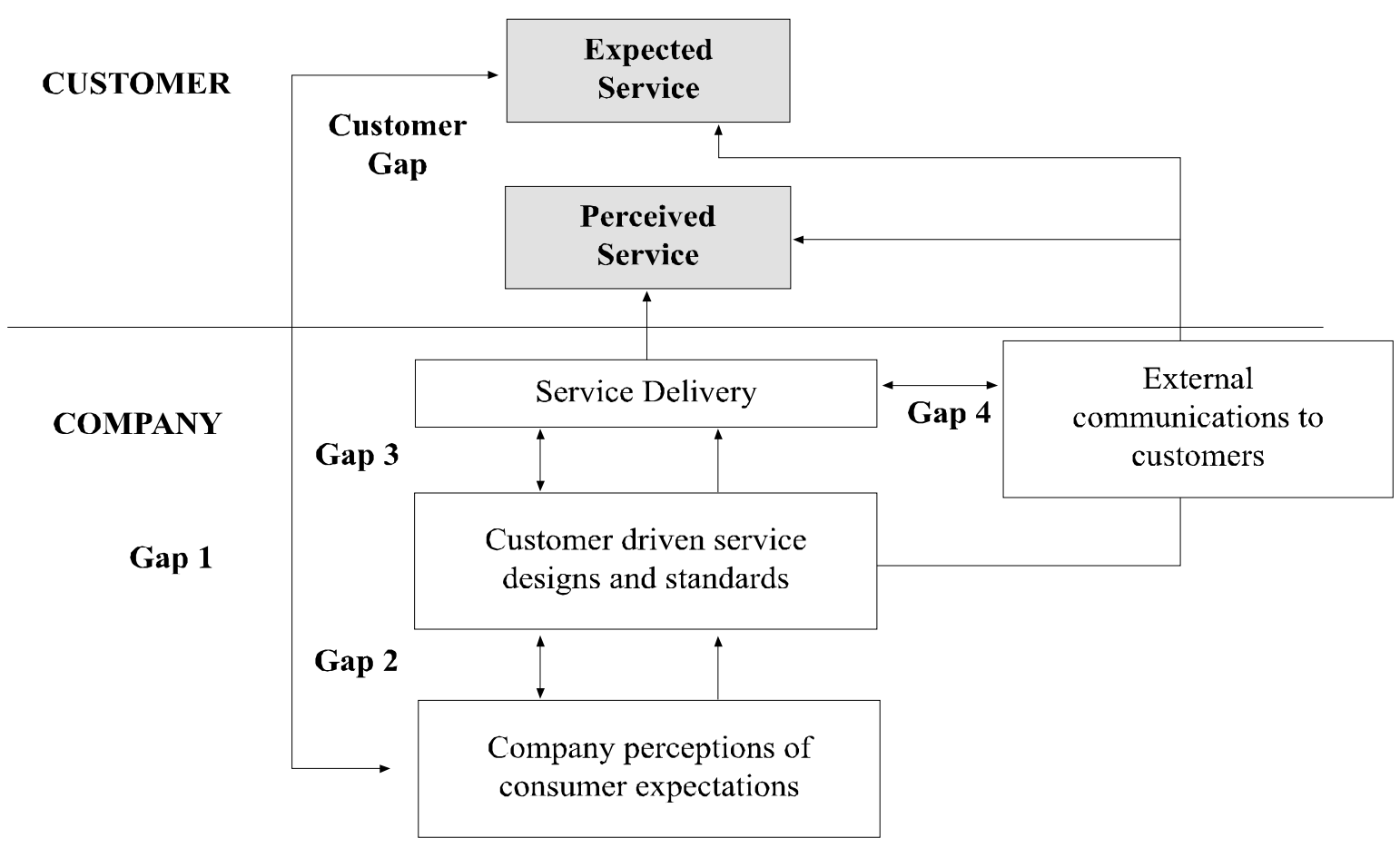

Source: Parasuraman, Zeithaml, and Berry, 1985, pp.44 
service experience. The performance of the service provider falls either below customers' expectations or above them. When expectations are exceeded, service is perceived to be of exceptional quality and also to be a pleasant surprise. When expectations are not met, service quality is deemed unacceptable. When expectations are confirmed by perceived service, quality is satisfactory. However, quality, which falls short of expectations, has a greater effect on customer satisfaction than quality which exceeds satisfaction (Zeithalm and Bitner, 2000). In the services sector, being different has a special advantage among rivals that offer similar goods and services (Fitzsimmons and Fitzsimmons, 1994). Implicitly or explicitly customers make comparisons among service standards of different firms.

\section{Figure 2. Perceived Service Quality}

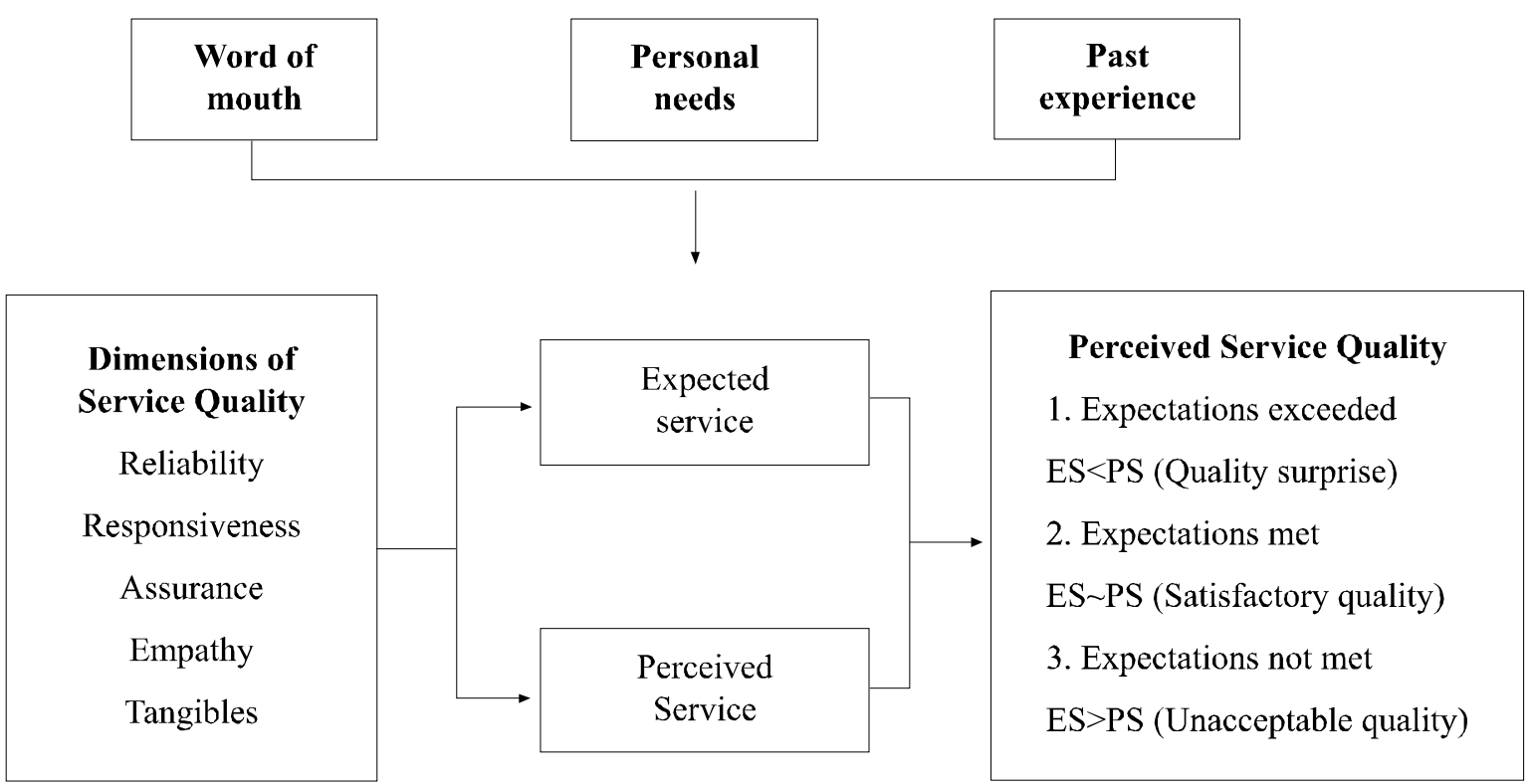

Source: Parasuraman, Zeithaml, and Berry, 1985, pp.48

\section{AIRLINE SERVICE QUALITY}

Services provided by airlines may not be physically complex like high tech products, but they are made up of a very complex mix of intangibles (Gursoy et al., 2005). Measuring customers' expectations and perceptions for airline services is a real challenge because customer satisfaction is determined by many intangible factors such as ambiance of the cabin, employee behaviors, etc. (Fitzsimmons and Fitzsimmons, 1994).

The main airline quality dimensions were emphasized in the current literature in several studies such as in flight activities (Alamdari, 1999), cabin (Tsaur et al., 2002; Westwood et al., 2000; Waikar and Nichols, 1997; Young et al., 1994), country of origin (Bruning, 1997), Internet services (Driver, 1999), convenience (Chang and Yeh, 2002; Waikar and Nichols, 1997;
Young, et al., 1994), airline employees (Chang and Yeh, 2002; Westwood et al., 2000).

Despite the considerable amount of research under service quality that has accumulated over the years (Cunnigham et al., 2002), few studies to date have examined customer expectations and perceptions of service quality in airline industry. Among these, the generally accepted measurement method, SERVQUAL model (Parasuraman et al., 1988), which assesses gaps between customer expectations of service quality and their perceptions of its actual delivery by the provider, is used extensively in the air travel industry (e.g. Young et al., 1994; Sultan and Simpson, 2000) . According to different studies, the SERVQUAL approach means simple and inexpensive instrument in analyzing service quality (Heung et al., 2000). Young et al., (1994) compared industry-based service quality dimensions with SERVQUAL-based dimensions in order to measure their ability in 
predicting customer satisfaction and intention to repatronize. They concluded that prediction of the factors affecting customer satisfaction and intention is clearly improved with the addition of SERVQUAL measures to the traditional measures. Sultan and Simpson (2000) using the SERVQUAL model have examined the variability of relative importance attributed to service quality dimensions in an international context and detected different expectations and perceptions based on nationality. Frost and Kumar (2000) taking the original Gap Model one step further and developing the Internal Service Quality Model has applied the latter to the internal marketing activities of Singapore Airlines Limited and Singapore Airport Terminal Services. Regarding service quality, in the study of Augustyn and Ho (1998), Fick and Ritchie (1991) suggested the SERVQUAL model as an instrument and they have investigated four different services like airline, hotel, restaurant and ski area services. Fick and Ritchie (1991) claim that the model can be successfully used to assess the magnitude of the gaps between the perceptions and expectations of internal customers.

\section{RESEARCH OBJECTIVES}

This study aims to explore (1) the expectations and perceptions of charter airline passengers. (2) It also questioned customer priorities in terms of expectations and perceptions for charter airline services. (3) The gaps between expectations and perceptions of customers for different airline service dimensions were identified. (4) The use of a more interpretive and visual statistical method for marketing managers is aimed. Correspondence analysis -a mapping technique- was used in order to provide the service managers the advantage of ease in analysis and interpretation.

\section{RESEARCH METHODOLOGY}

The research was conducted between July and August flights of SunExpress. Because it is the busiest period for tourist arrivals and departures in Antalya region, this period was chosen. The city of Antalya was selected because of its tourist potential. In 2005, total number of charter flights was 71,286, and in 2006 total number of passengers' arrivals at Antalya International Airport was $6,125,494$. Germany was by far the biggest market of origin for surpassing with 1,880,746 arrivals, Russia with 1,276,489 and Holland with 358,595 arrivals (Ministry of Culture and Tourism, 2007).

As a sampling procedure, the convenience method of non-probability sampling is used. Flights were selected randomly from the flight schedule during that period. All the destinations that SunExpress flights from Antalya were covered. Passengers were selected randomly according to the predetermined seat numbers in each flight. The data collection process was realized in close cooperation with the marketing department of SunExpress. A total of 750 questionnaires were delivered to the SunExpress marketing department for completion in the cabins randomly during the flight. At the end of the period, 235 usable questionnaires $(31.3 \%$ response rate) were gathered from the marketing department.

In the item generation phase of the initial questionnaire, so as to fit the measurement of charter airlines' service quality, many of the items were adapted from the study of Aksoy et al. (2003) that had examined aspects of airline service dimensions. Rests of the items (such as in-flight activities) were generated in cooperation with charter airline senior executives in line with the requirements' of charter airline services. The comments of senior executives were used to determine the service details that SunExpress offers as a charter airline to their passengers in creating value. Since senior executives work more closely and have more direct relations with the airline customers, their evaluations were required for the academic study which also guaranteed the face validity. Finally, a specific research questionnaire was developed, covering almost all aspects of charter airline services from the customers' perspective. After these executive and academic reviews, the final questionnaire contained 38 different statements concerning various service attributes on which the passengers were asked to indicate their "expectations" and "perceptions" separately. According to the service quality gap analysis, a two-step data collection method was required for measuring the airline passengers' expectations and perceptions. Due to the difficulties in obtaining two separate questionnaires from the same group of passengers, expectation and perception statements were written in the same questionnaire respectively. To test the perceptions regarding airline services dimensions, it is asked to the cabin personnel to deliver the questionnaires at the near end of the flight duration on air. In the first part of the questionnaire, respondents were asked to indicate their expectations by assessing the level of importance they attach to a set of 38 statements on a seven point Likert scale (with $1=$ "totally agree"; 7= "totally disagree"). The second part of the questionnaire includes the same questions in order to measure the perceptions of service quality for SunExpress. Apart from the service quality items, there were also other questions that probed demographic characteristics. 


\section{FINDINGS}

\section{DEMOGRAPHIC PROFILE OF THE PASSENGER}

\section{GROUP}

The demographic profiles of the respondents traveling by SunExpress were summarized separately in Figure 3. Respondents were more or less equally distributed between males (46.5\%) and females (53.5\%). Majority of the passengers $(33.2 \%)$ were aged between $31-40$. In terms of nationality, most of the passengers were German and living in Germany.

Figure 3. Demographic Profiles

\section{GENDER}

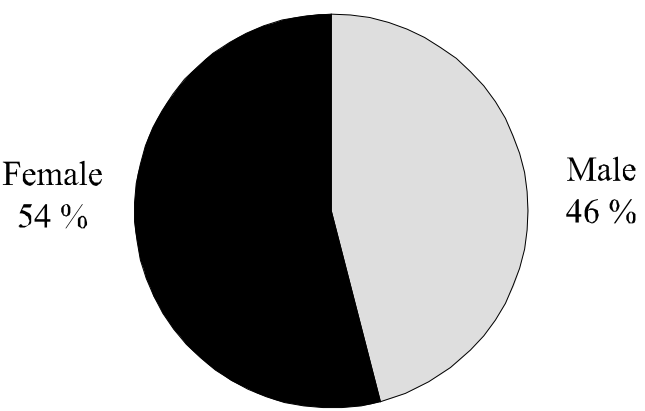

RESIDENCE

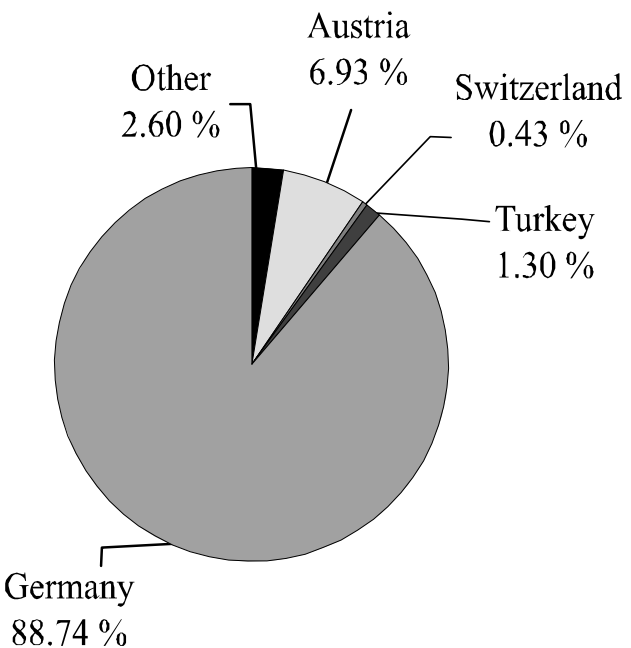

\section{NATIONALITY}

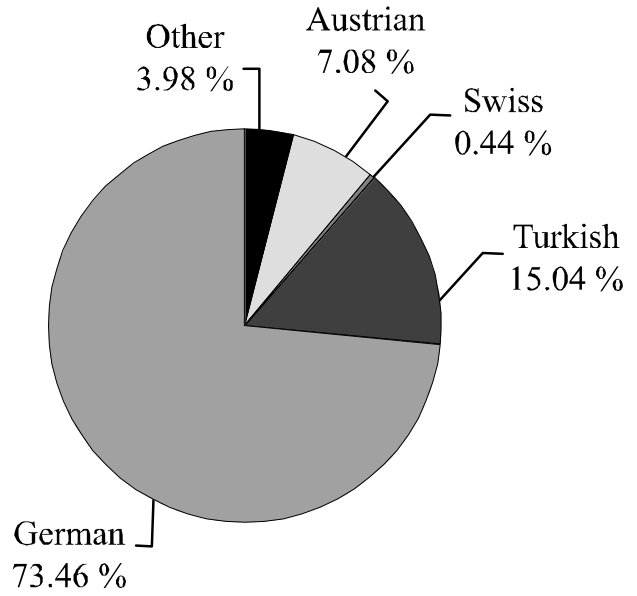

AGE

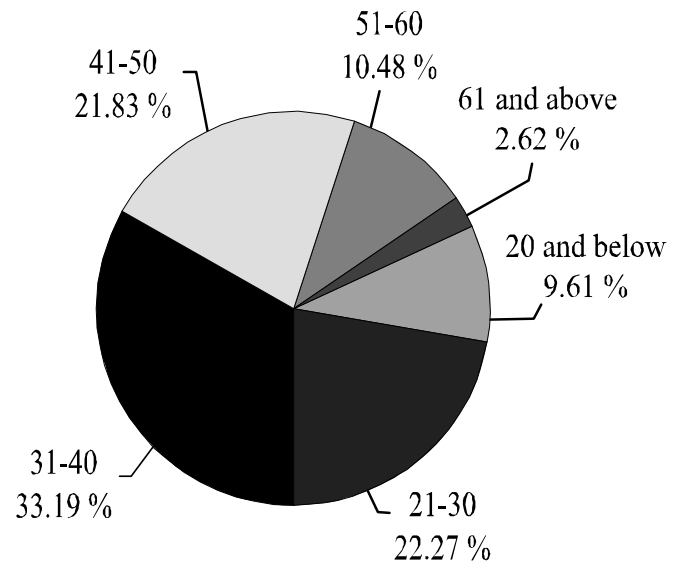




\section{EXPEXTATION AND PERCEPTION GAPS BY UNDERLYING DIMENSIONS}

In order to measure the gaps between the expected and perceived service levels, the 38 statements which have a Cronbach's alpha of 0.93 were grouped under eight major airline service dimensions. Then, to assess the significance difference of the arithmetic means for each dimension, pairwise $t$-tests were performed between expectation and perception scores. According to the results, mean differences between the expected and perceived service levels regarding all of the eight dimensions were statistically significant (see Table 1). This demonstrated us that there were service quality gaps in all service categories. Further look into the paired differences in Table 1 also showed that the widest gap was in the INTERNET services, followedby the FOOD \& BEVERAGE services.
To draw a better picture of the passenger expectations and perceptions, a statistical mapping technique correspondence analysis (CA)- was used through which the dimensions were mapped against passenger expectations and perceptions respectively (Atilgan et al., 2003). CA is an exploratory multivariate technique that converts a matrix of non-negative data into a particular type of graphical display in which the rows and columns of the matrix are depicted as points (Greenacre and Hastie, 1987). Correspondence analysis scales the rows and columns in corresponding units so that each can be displayed graphically in the same two-dimensional space. The advantage of correspondence analysis, as compared with other multidimensional scaling techniques, is that it reduces the data-collection demands imposed on the respondents (Malhotra, 1999).

Table 1. Service Quality Gaps

\begin{tabular}{|l|r|r|r|r|r|}
\hline Airline Service Dimensions & Expectations & Perceptions & Paired & t-values & Sig. (2-tailed)* \\
& Mean & Mean & Mean & & \\
\hline & 1.76 & 2.33 & $\mathbf{. 5 6 6 9}$ & 7.48 & .000 \\
\hline INTERNET & 1.88 & 2.42 & .5300 & 8.01 & .000 \\
\hline FOOD \& BEVERAGE & 1.58 & 1.97 & .3946 & 7.34 & .000 \\
\hline CABIN & 2.09 & 2.46 & .3676 & 4.12 & .000 \\
\hline AESTHETICS & 2.71 & 3.00 & .2792 & 5.96 & .000 \\
\hline CONVENIENCE & 1.73 & 2.00 & .2576 & 5.30 & .000 \\
\hline DEPENDABILITY & 2.21 & 2.46 & .2462 & 5.29 & .000 \\
\hline IN FLIGHT ACTIVITIES & 1.60 & 1.77 & .1560 & 3.86 & .000 \\
\hline PERSONNEL & & & & \\
\hline
\end{tabular}

Note: *denotes that there is a significant difference between (E) and (P) at 95 per cent confidence level 
Figure 4. Service Quality Expectations

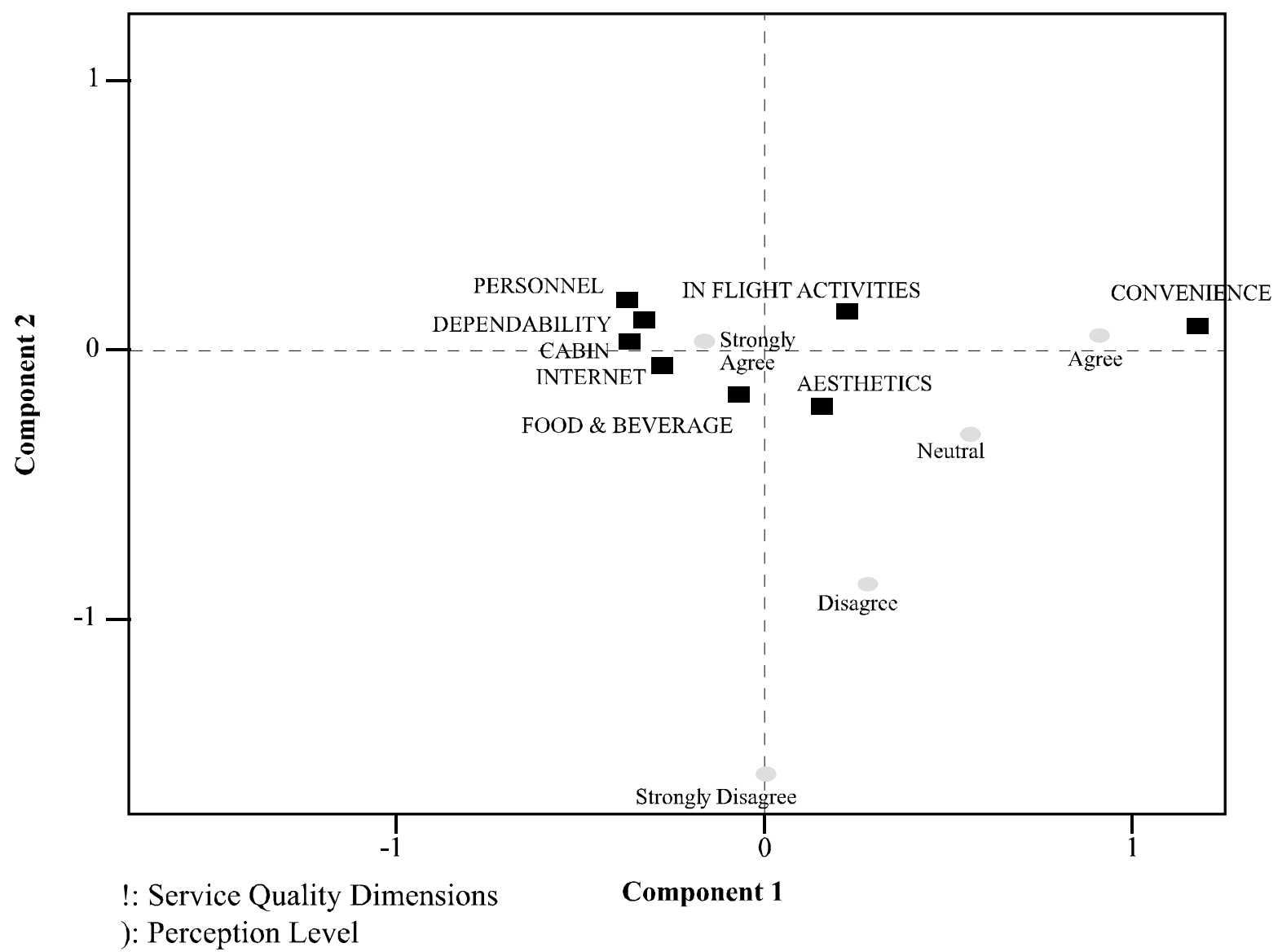

As depicted in Figure 4, the charter airline passengers' expectations regarding personnel, food and beverage, cabin features, Internet and dependability were all grouped around the "strongly agree" category. Passengers had the highest expectation levels for these dimensions. If specific service attributes under each dimension were examined, further insights could be obtained about the customers' needs. For the PERSONNEL dimension, attributes of special importance were indicated to be service delivery on promises, willingness to help passengers, trust, confidence, and empathy. Another major airline service dimension, FOOD \& BEVERAGE, covered the quality, amount, timeliness and variety of the food and beverages served during the flight. Airline passengers also displayed high levels of expectations for CABIN features such as ventilation, temperature, cleanliness, seat comfort and carry-on (overhead) storage space. In terms of DEPENDABILITY, expectations showed that passengers were looking for on-time departures and arrivals, on-time luggage delivery on arrival, correct flight information and records. Opportunity of reservation and buying ticket via Internet formed the common INTERNET attributes. Following these main dimensions of high expectations, IN-FLIGHT ACTIVITIES and AESTHETICS took an important place in passengers' minds. Although CONVENIENCE dimension was also important for airline services, according to the nature of charter airlines, passengers gave less importance to the convenience in making reservation/booking and frequent flights to destinations. The reason for this was that charter airline passengers generally buy these flights in a holiday package and tour operators handle all these arrangements.

Figure 4 also depicted that none of the service dimensions should be overlooked or underestimated, by service providers since none of them was positioned close to the "strongly disagree" and "disagree" category. Not surprisingly, airline passengers, like every consumer, expect high levels of service from the service providers, but the noteworthy point for managers is that passengers may attach different importance levels to each service dimension. 
Figure 5. Service Quality Perceptions

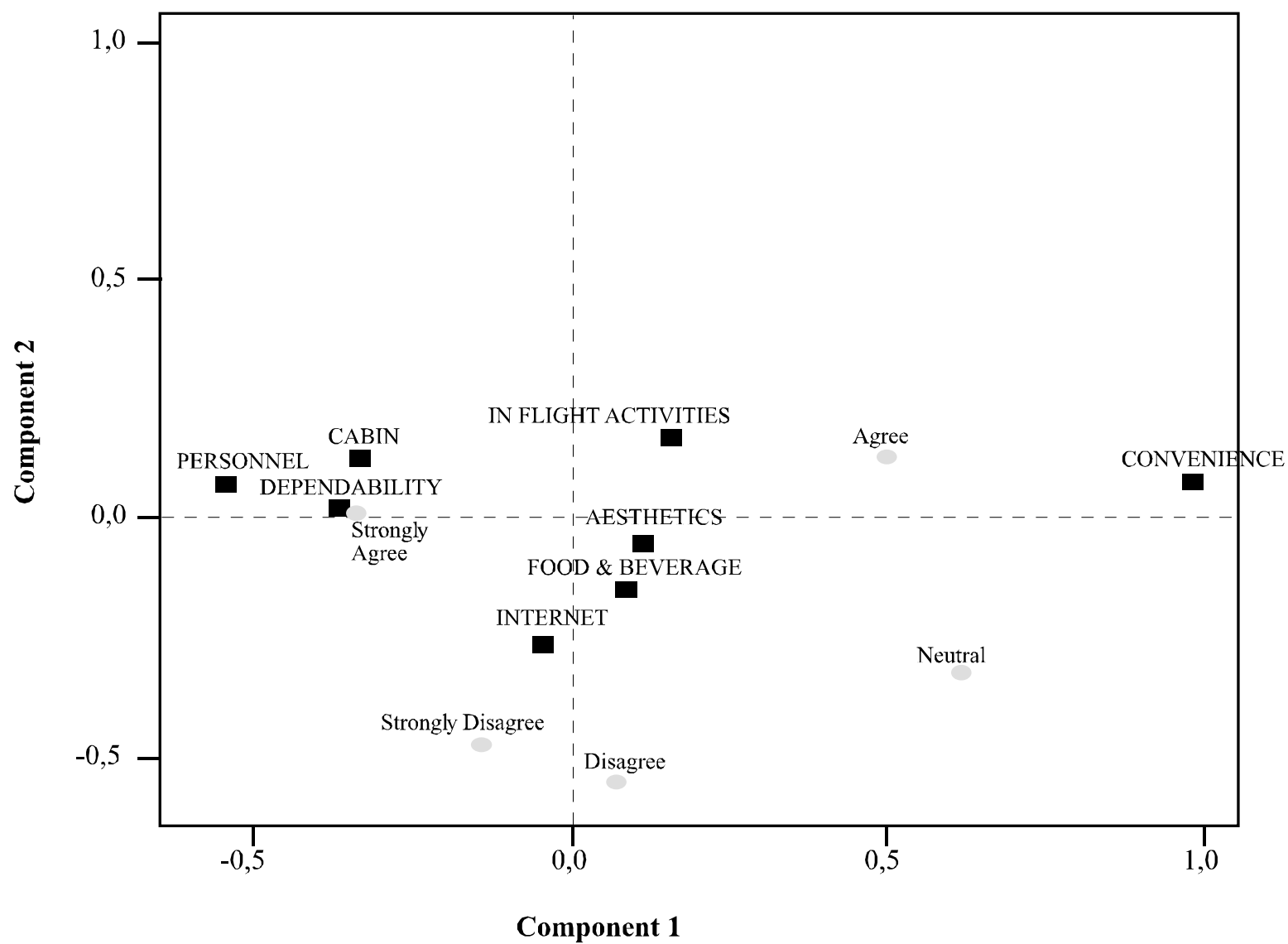

!: Service Quality Dimensions

): Perception Level

Charter passengers' perceptions were to a great extent parallel to their expectation levels except, INTERNET and FOOD \& BEVERAGES attributes (see Figure $5)$. They "strongly agreed" with the high performance of SunExpress in terms of DEPENDABILITY, PERSONNEL, and CABIN which were positioned as the key factors for a perfect service. The perceived performance of SunExpress in INTERNET services and FOOD \& BEVERAGES, on the other hand, could not meet with the expectations of the passengers.

\section{STRATEGIC OUTLOOK FOR THE SERVICE GAPS}

One of the most useful forms of strategic analysis in marketing research is the importance/performance matrix. It combines information about customer perceptions and importance ratings. In investigating Sun Express's current performance level, a strategic outlook analysis by plotting Sun Express's expectation and performance data on the expectation/performance grid was shown in Figure 6.

To understand the expectation/performance analysis (EPA) results, the grid was divided into four different quadrants (I-IV). The EPA grid results depicted that customers' perceptions of Sun Express's services did not exactly match with their expectations. The service dimensions that took place in quadrants I and II illustrate the dimensions that passengers had the highest expectations. Among the top five service expectation dimensions deemed extremely or very important to passengers, only the PERSONNEL dimension was viewed as having excellent or better performance. It was positioned in Quadrant II which illustrated the situation where customers exhibited a high value toward a given feature and were pleased with that feature's perceived performance (high expectation and high performance). The two most important features, FOOD \& BEVERAGE and INTERNET, were viewed as being at the poor to fair levels (see Quadrant I). It depicted the situation where customers 
Figure 6. Expectation/Performance Analysis

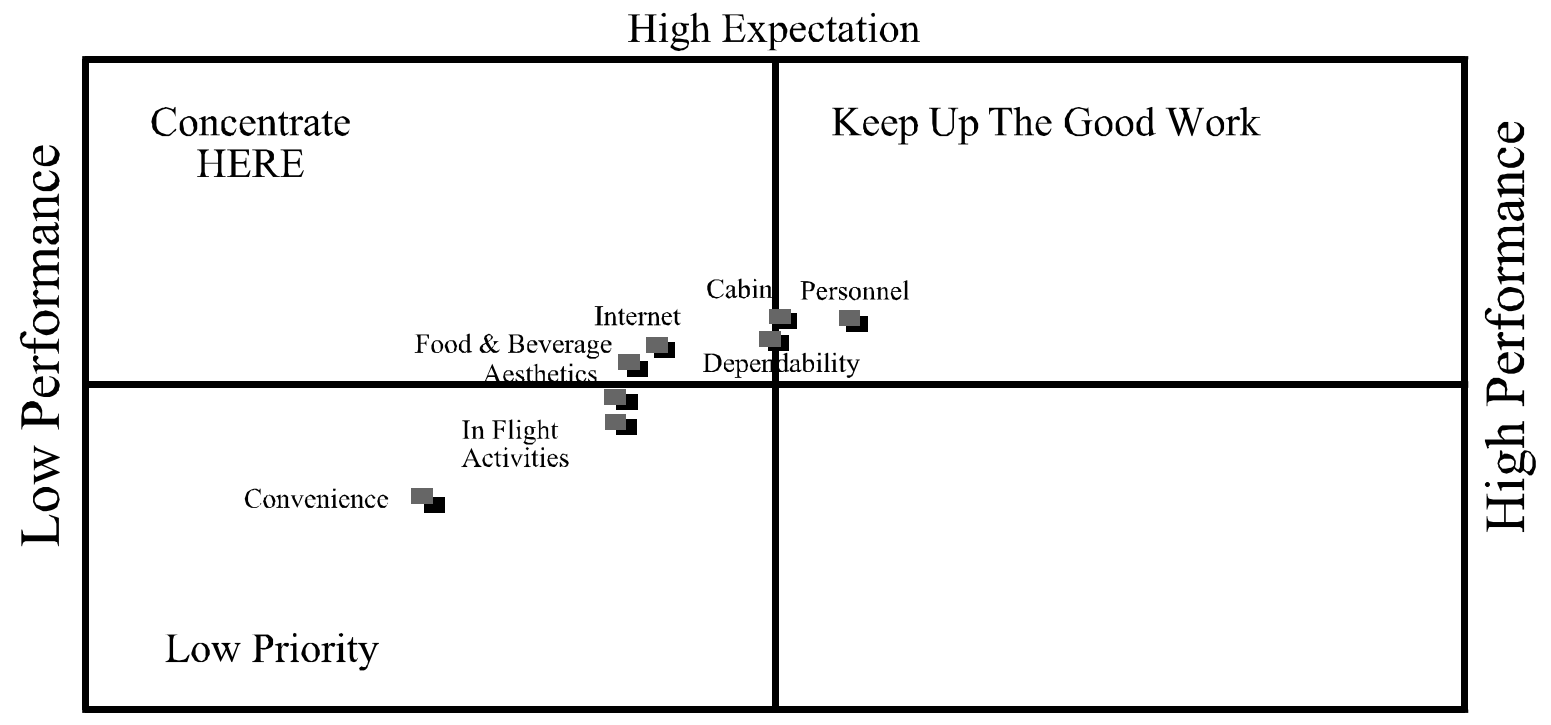

Low Expectation

had high levels of service expectations but indicated low perceptual satisfaction with the charter airline's performance (high expectation but low performance). Passengers evaluated the CABIN and DEPENDABILITY attributes just in the middle of the two quadrants (I and II) where significant attention should also be placed on.

Performance levels of aesthetics, in-flight activities and convenience were only marginally important to customers, but at the same time Sun Express's current performance on these dimensions were also below than other service dimensions. Quadrant III was the place where the dimensions were perceived as low in terms of performance but consumers did not consider it as being very important.

\section{CONCLUSION}

Like other service industries, the speed and intensity of change in offers has accelerated in recent years within airline industry. Customer needs are growing in variety, challenge in the markets is becoming globally tough and cost and price structures are becoming more transparent. In such an occasion, airline senior managers should be aware of the shift for reacting accurately on time. Timely and relevant information on a wide range of customer needs and expectations become critically important.

Managers should be more precise about the measurement of the two concepts, expectations and perceptions. The difference between service expectations and perceptions is the growing concern of service providers. In this respect, the result of the gap analysis showed that the biggest service gap occurs in Internet dimension, which means customers expectations, are above the service providers' performance. This may be the result of rapid change in technology that permits people easier information search, and transactions, and less cost and time. Most of the airlines re-design their web sites according to the increasing customer demand.

Also, an application of gap analysis with correspondence analysis (CA) is used from a different perspective that permits interpretation of the results visually. Each airline service quality dimension is analyzed with CA and customer expectations and perceptions are both mapped. As a result, customers have relatively higher expectations on personnel, dependability, cabin, Internet, food and beverage dimensions. In terms of customers' perceptions, likewise, personnel, dependability, and cabin dimensions resulted in relatively high rating. This study allows the airline management to see the expectancy level of customers for each specific airline service attribute, prioritize different service attributes based on customer expectations, measure the perceived service levels by customers and compare them with more tangible data (internal records, industry standards, competitors' practices, etc.). Also, identifying the service quality gaps for specific service attributes guide the airline management to tailor its service offering for higher customer satisfaction. Mapping and measuring expectations and perceptions of customers with the studied method provides 
convenience and efficiency as it is a direct, flexible, and economical way of measuring quality from the consumer's perspective for the company management. Finally, in line with the results of gap analysis, EPA grid helps to form a strategic outlook for decision makers.

\section{LIMITATIONS AND DIRECTIONS FOR FUTURE RESEARCH}

Some limitations of the present study must also be acknowledged. First, the major customer segment of the sample airline consists of German passengers. The ranking of the gaps between airline service quality dimensions could be different for culturally different passenger segments. Secondly, despite the leader position of SunExpress within the charter airlines in Turkey, results represent only the mentioned airline's passengers. In addition to these limitations, it can be said that the questionnaire for the sample was limited to the cabin. In order to evaluate the overall quality of service in the airline industry in-flight service, ground service and cargo service must be investigated in researches.

\section{REFERENCES}

Aksoy, Ş., Atilgan, E. and Akinci, S. (2003), Airline services marketing by domestic and foreign firms: differences from the customers' viewpoint, Journal of Air Transport Management, 9(6), pp. 343-351.

Alamdari, F. (1999), Airline in-flight entertainment: the passengers' perspective, Journal of Air Transport Management, 5, pp.203-209.

Atilgan, E., Akinci, S. and Aksoy, Ş. (2003), Mapping service quality in the tourism industry, Managing Service Quality, 13 (5), pp. 412-422.

Augustyn, M. and Ho, S.K. (1998), Service quality and tourism, Journal of Travel Research, 37 (1), pp.7175.

Brady, M. K. and J. J. Cronin (2001), Some new thoughts on conceptualizing perceived service quality: A hierarchical approach, Journal of Marketing, 65 (3), 34-49.

Brown S.W. and Bond E.U. (1995), The Internal and External Framework and Service Quality: Toward Theory in Services Marketing, Journal of Marketing Management, 23, pp. 25-39.

Brown, T. J., G. A. Churchill, and J. P. Peter (1993), Improving The Measurement Of Service Quality, Journal of Retailing, 69 (1), 127-39.

Bruning, E.R. (1997), Country of origin, national loyalty and product choice: the case of international air travel, International Marketing Review, 14, pp. 59-74.

Chang, Y. and Yeh, C. (2002), A survey analysis of service quality for domestic airlines, European Journal of Operational Research, 139(1), pp.166-177.

Cunnigham, L.F., Young, C.E. \& Lee, M. (2002), Cross-cultural Perspectives of Service Quality and Risk in Air Transportation, Journal of Air Transportation, 7(1), 3-27.

Dabholkar, Thorpe ve Rentz (1996), A Measure of Service Quality for Retail Stores: Scale Development and Validation, Journal of the Academy of Marketing Science, 24 (2), 3-16.

De Lollis, B. (2002), Airlines Continue Revenue Search, USA Today, July, p.3B.

Driver, J.C. (1999), Developments in airline marketing practice, Journal of Marketing Practice: Applied 
Marketing Science, 5, pp. 134-150.

Fick, G.R. and Ritchie, J.R.B. (1991), Measuring service quality in the travel and tourism industry, Journal of Travel Research, 30 (Fall)pp.2-9.

Fitzsimmons J. and Fitzsimmons M.J. (1994), Service Management for Competitive Advantage, New York, McGraw Hill Inc.

Frost, F.A. and Kumar, M. (2000), INTSERVQUAL - an Internal Adaptation of the GAP Model in a Large Service Organization, Journal of Services Marketing, 14(4/5), pp.358-377.

Greenacre, M. and Hastie, T. (1987), The geometric interpretation of correspondence analysis, Journal of American Statistical Association, 82(398), pp. 43747.

Gursoy, D., Chen, M. and Kim, H.J. (2005), The US Airlines Relative Positioning Based on Attributes of Service Quality, Tourism Management, 26(1), pp. 5767.

Heung, V.C.S., Wong, M.Y. and Qu, H.(2000), Airport - Restaurant Service Quality in Hong Kong: an Application of Servqual, Cornell Hotel and Restaurant Administration, 41 (3), pp. 86-96.

Malhotra, N.K. (1999), Marketing Research, PrenticeHall, London.

Ministry of Culture and Tourism, Turkey (2007). Statistics and Researches, (accessed March 28, 2007), [available at

http:.//www.kultur.gov.tr/portal/istatistik_tr.asp]

Parasuraman A., Zeithaml V., and Berry L.L. (1985), A Conceptual Model of Service Quality and its Implication for Future Research, Journal of Marketing, 49.

Parasuraman A., Zeithaml V., and Berry L.L. (1988), SERVQUAL: a Multiple Item Scale for Measuring Customer Perceptions of Service Quality, Journal of Retailing, 64(1), pp. 12-43.

Peter, J. P., G. A. Churchill, and T. J. Brown (1993), Caution In The Use Of Difference Scores In Consumer Research, Journal of Consumer Research, 19 (4), 65562 .

Robledo, M.A. (2001), Measuring and Managing Service Quality: Integrating Customer Expectations, Managing Service Quality, 11(1), pp. 22-31.
Sultan Jr., F. and Simpson, M.C. (2000), International Service Variants: Airline Passenger Expectations and Perceptions of Service Quality, Journal of Services Marketing, 14, pp. 188-216.

Teas, R. K. (1993), Expectations, Performance Evaluation, And Consumers Perceptions Of Quality, Journal Of Marketing, 57 (4), 18-34.

Tsaur, S., Chang, T. and Yen, C. (2002), The Evaluation of Airline Service Quality By Fuzzy MCDM, Tourism Management, 23, pp. 107-115.

Waikar, A. and Nichols, P. (1997), Aviation Safety: a Quality Perspective, Disaster Prevention and Management, 6, pp. 87-93.

Westwood, S., Pritchard, A. and Morgan, N.J. (2000), Gender-Blind Marketing: Businesswomen's Perceptions of Airline Services, Tourism Management, 21, pp. 353-362.

Young, C., Cunningham, L. and Moonkyu, L. (1994), Assessing Service Quality as an Effective Management Tool: The Case of The Airline Industry, Journal of Marketing Theory and Practice, 2, pp. 76-97.

Zeithaml, V.A. and Bitner, M.J. (2000), Services Marketing: Integrating Customer Focus Across the Firm. McGraw-Hill, Madison. 